\title{
ACADEMIC TENURE AND ACADEMIC FREEDOM
}

\author{
Ralph S. Brown* and Jordan E. Kurland**
}

\section{INTRODUCTION}

Anyone with enough interest in academic tenure to glance at this article knows what tenure is.

Are you sure? Here are two rather varying definitions. The first, by a former president of Yale University, Kingman Brewster, is from the best brief statement about tenure in a research university: "The practical fact in most places, and the unexceptional rule at Yale, is that tenure is for all normal purposes a guarantee of appointment until retirement age." 1 The second, by Duke law professor William W. Van Alstyne, is found in the best general defense of tenure: "Tenure, accurately and unequivocally defined, lays no claim whatever to a guarantee of lifetime employment. Rather, tenure provides only that no person continuously retained as a full-time faculty member beyond a specified lengthy period of probationary service may thereafter be dismissed without adequate cause."2

Both definitions are close to the truth: President Brewster's as a realistic observation, Professor Van Alstyne's as a cautious scholar's synthesis. We will have more to say about their apparent differences. The conventions and legal status that both address affect all but a very few of the nation's accredited universities and four-year colleges. ${ }^{3}$ This article will say little or nothing

Copyright $\mathcal{C} 1990$ by Law and Contemporary Problems

* Simeon E. Baldwin Professor Emeritus, Yale Law School.

* Associate General Secretary, American Association of University Professors.

When this article was prepared, Brown was serving as interim general counsel of AAUP. It is accordingly important to declare that neither author is speaking for the AAUP, although, as will appear, both draw heavily from AAUP policies and practices, and from their own long experience in the AAUP. Brown is the primary author of Parts I-VI, Kurland of Part VII. However, they share responsibility for the total effort.

1. Kingman Brewster, Jr., On Tenure, 58 AAUP Bull 381 (1972) (excerpted from his 1971-72 Report as President of Yale University).

2. William W. Van Alstyne, Tenure: A Summary, Explanation, and "Defense," 57 AAUP Bull 328 (1971) (emphasis in original). Further, Van Alstyne writes,

[i]t is but a limited statement that each faculty member possessing it, receiving it only after a stipulated period of probationary service, is thought worthy of a rebuttable presumption of professional excellence in continuing service to the institution. Thereafter, when termination of his services is sought for any reason inconsistent with that presumption, it requires only that the burden of justification be fairly discharged under conditions of academic due process by those with whom it properly rests. Id at 329.

3. Colleges with no tenure system are at some risk of winding up on the AAUP's list of Censured Administrations (reprinted regularly in AAUP's Academe). A recent instance is Alvernia 
about two-year community colleges. While two-year institutions account for almost 40 percent of post-secondary enrollments, ${ }^{4}$ their practices range from a tenure system following the higher education model, to the public school model of granting tenure routinely after the teacher has served for two or three years without running into difficulties, to no tenure system at all. ${ }^{5}$

The conventions and entitlements of tenure have existed for generations. Walter Metzger, in a comprehensive historical essay on academic tenure, describes the judicial mode of controlling dismissals demonstrated by university tribunals affording due process. ${ }^{6}$ Metzger ascribes the recognition of the judicial mode to the famous 1915 "philosophical birth cry" 7 of the American Association of University Professors ("AAUP"), the Declaration of Principles of its Committee on Academic Freedom and Academic Tenure. That Declaration, in its "Practical Proposals," declared firmly that

[i]n every institution there should be an unequivocal understanding as to the term of each appointment; and the tenure of professorships and associate professorships, and of all positions above the grade of instructor after ten years of service, should be permanent (subject to the provisions hereinafter given for removal upon charges). ${ }^{8}$

The next major milestone in the development of tenure was the 1940 Statement of Principles on Academic Freedom and Tenure. ${ }^{9}$ While the 1915 Declaration was the work of a committee of professors, the 1940 Statement was a joint production of professors and university and college presidents. ${ }^{10}$ Endorsed by the Association of American Colleges ("AAC") (and over the ensuing fifty years by more than 140 professional organizations), ${ }^{11}$ the 1940 Statement proclaimed that

[t]enure is a means to certain ends; specifically: (1) Freedom of teaching and research and of extramural activities and (2) a sufficient degree of economic security to make the profession attractive to men and women of ability. Freedom and economic security, hence, tenure, are indispensable to the success of an institution in fulfilling its obligations to its students and to society. ${ }^{12}$

College (Pennsylvania), the subject of a report in 76 Academe 67 (January-February 1990), and censured in June 1990.

4. U.S. Bureau of the Census, Statistical Abstract of the U.S. 153 (110th ed 1990).

5. In $1987,62 \%$ of public two-year colleges had a tenure system, compared to $99 \%$ of fouryear public institutions, according to a 1988 U.S. Department of Education survey reported in Carolyn J. Mooney, New U.S. Survey Assembles a Statistical Portrait of the American Professoriate, Chron Higher Educ A15, A19 (February 7, 1990).

6. Walter P. Metzger, Academic Tenure in America: A Historical Essay, in Commission on Academic Tenure in Higher Education, Faculty Tenure 93 (Jossey-Bass, 1973) ("Academic Tenure"). The pioneering work on tenure practices and law is Clark Byse \& Louis Joughin, Tenure in American Higher Education: Plans, Practices, and the Law (Cornell Univ Press, 1959).

7. Metzger, Academic Tenure at 148 (cited in note 6).

8. General Report of the Committee on Academic Freedom and Academic Tenure, 1 AAUP Bull 17, 40-41 (1915) ("1915 Declaration"); see Appendix A, 53 L \& Contemp Probs 393, 405-06 (Summer 1990).

9. 1940 Statement of Principles on Academic Freedom and Tenure ("1940 Statement"), in Policy Documents and Reports 3 (AAUP, 1984) ("1984 AAUP Red Book"); see Appendix B, 53 L \& Contemp Probs 407 (Summer 1990).

10. See Walter P. Metzger, The 1940 Statement of Principles on Academic Freedom and Tenure, 53 L \& Contemp Probs 3 (Summer 1990).

11. There was an intermediate "Conference Report" of 1925, not germane to this survey. For the most recent list of endorsers of the 1940 Statement, see AAUP, Policy Documents and Reports 3 (AAUP, 1990) (“1990 AAUP Redbook").

12. 1940 Statement at 3; Appendix B at 407 (cited in note 9). 
Here one finds a second emphasis—on economic security-and, further on in the Statement, a refinement of procedural protections, along with a shortening of the allowable probationary period to seven years.

The 1940 Statement marks the maturity of the linkage of academic tenure to academic freedom. The Statement-incorporated, often verbatim, in the policies of hundreds of colleges and universities-is the yardstick for measuring adherence to proper standards of academic freedom and tenure. ${ }^{13}$ Although many would limit academic freedom, some very seriously, hardly anyone nowadays attacks it head on. But academic tenure is always under attack. Usually we hear only grumbling and rumbling, as of distant artillery. But occasionally there is a prolonged fire-fight. The last such episode flared up in the early 1970s, when the long postwar expansion of higher education slowed. Jobs became scarce. Many institutions that had been lavish in conferring tenure proclaimed themselves "overtenured."14 Much of the disputation upon which this paper relies comes from that decade. ${ }^{15}$ Now, in 1990 , the pendulum may have swung. Those hired to teach the baby-boomers are approaching retirement. We are told that there will be more jobs. ${ }^{16}$ Yet dissatisfaction still surfaces. ${ }^{17}$ It is noteworthy that proponents of tenure are perennially on the defensive; recall the title of Van Alstyne's article, Tenure: $A$ Summary, Explanation, and "Defense." 18 The attacks tend to be hit-and-run; ${ }^{19}$ the defensive statements are more sustained. ${ }^{20}$

13. "Probably because it was formulated by both administrators and professors, all of the secondary authorities seem to agree that it is the "most widely-accepted academic definition of tenure'." Krotkoff v Goucher College, 585 F2d 675, 679 (4th Cir 1978) (citations omitted). See generally Note, The Role of Academic Freedom in Defining the Faculty Employment Contract, 31 Case W Res L Rev 608 (1981) (authored by Richard H. Miller); Ralph S. Brown \& Matthew W. Finkin, The Usefulness of AAUP Policy Statements, 59 Educ Record 30 (1978).

14. See Fred M. Hechinger, Job Crunch Spurs Debate on Tenure, New York Times $\$ 3$ at 5 col 4 (January 16, 1979). After noting the "huge expansion" of the 1950s and 1960s, and the attendant "crippling shortage of teachers," Hechinger writes that "[f]aculty members were hired . . . with a diminishing concern for their true, lasting capacities. Often, they were given tenure after less than complete scrutiny. Such profligate uses of tenure did much to bring it into disrepute." Id.

15. See also Malcolm G. Scully, Attacks on Tenure Mount; Limitations are Proposed in 5 States, Chron Higher Educ 1 (March 22, 1971) ("Attacks on Tenure Mount").

16. See William G. Bowen \& Julie Ann Sosa, Prospects for Faculty in the Arts and Sciences: A Study of Factors Affecting Demand and Supply, 1987-2012 134-35, 142-43 (Princeton Univ Press, 1989). Carolyn J. Mooney, Uncertainty is Rampant as Colleges Begin to Brace for Faculty Shortages Expected to Begin in 1990s, Chron Higher Educ Al4 (January 25, 1989).

17. See, for example, Page Smith, Killing the Spirit: Higher Education in America 114-22 (Viking Press, 1990) ("Killing the Spirit").

18. See note 2.

19. A recent instance is a short editorial piece, The Tenure Temptation: Don't Give Professors Lifetime Jobs, 302 The Economist 15 (February 28, 1987).

20. In the last 20 years, there has been an impressive array of statements that, on balance, support academic tenure. A varied collection of essays-some critical-is Bardwell L. Smith \& Associates, eds, The Tenure Debate (Jossey-Bass, 1973). In the same year appeared Faculty Tenure (cited in note 6), the report of an independent Commission on Academic Tenure in Higher Education sponsored by the AAC and the AAUP, and funded by the Ford Foundation. Two university committees produced substantial reports that, even though they reflect the acute tensions of their times, have continuing interest: University of Utah Commission to Study Tenure, 57 AAUP Bull 421 (1971); Academic Tenure at Harvard University, 58 AAUP Bull 62 (1972). See also Fritz Machlup, In Defense of Academic Tenure, 50 AAUP Bull 112, 118 (1964). A recent temperate appraisal is Henry 
Although this paper will accentuate the affirmative, it too will unavoidably take a counter-attacking posture. Part II will address briefly the heart of the matter: does academic tenure reinforce academic freedom? Of course it does. We will then consider in Part III the asserted costs of tenure and the reasons behind the chronic criticism. Part IV, accepting the significant economic and social costs of tenure, will describe other substantial advantages of the practice, beyond the direct safeguarding of academic freedom. We will then ask in Part $\mathrm{V}$ whether alternative devices would effectively protect academic freedom-devices such as legal defenses, internal safeguards, lessthan-career tenure, or tenure reviews-and conclude that they would not. Part VI examines leaks in the dike of conventional tenure: due process deficiencies; the extent to which tenure may be undermined by financial exigency claims or by discontinuing entire programs; and the unease occasioned by the coming demise of mandatory retirement. Part VII turns to the plight of the untenured. What protects their academic freedom?

\section{II}

\section{Academic Tenure as the Primary Defense of Academic FREEDOM}

The conferral of tenure makes it very difficult thereafter to dismiss a professor for views expressed in the classroom, in scholarly writing, or in public arenas. ${ }^{21}$ As Van Alstyne's definition emphasizes, the university has the burden of demonstrating that the faculty member has said or done things offensive enough to warrant dismissal. But there is more involved than burden of proof. What constitutes adequate cause for dismissal? Some university regulations provide laundry lists of potential offenses, but more are silent on the matter. A fairly standard formulation would resemble the recommendation of the 1973 Commission on Academic Tenure, that " 'adequate cause' in faculty dismissal proceedings should be restricted to (a) demonstrated incompetence or dishonesty in teaching or research, (b) substantial and manifest neglect of duty, and (c) personal conduct which substantially impairs the individual's fulfillment of his institutional responsibilities." 22

There seems to be little room here for seizing on heterodox or unpopular views as a ground for dismissal or for any lesser sanction. It would be possible to argue in extreme cases that a scholar who published wildly was incompetent; but we know of no such recent actual cases (as distinct from general allegations of incompetence found in hostile criticisms of tenure).

Rosovsky, The University: An Owner's Manual 117-87, 189-212 (W. W. Norton, 1990) ("The University").

21. The important study, Howard R. Bowen \& Jack H. Schuster, American Professors: A National Resource Imperiled 235-44 (Oxford Univ Press, 1986) ("American Professors"), in a significant passage supporting tenure, but decrying certain rigidities in "present rules and practices," id at 244, declares that the procedures for ridding the profession of misfits are so arduous and embarrassing that they take on the flavor of a trial for murder, id at 243.

22. Commission on Academic Tenure in Higher Education, Faculty Tenure at 75 (cited in note 6). 
The word "dishonesty" can, of course, be twisted to fit an accusation that the scholar who advances unpopular beliefs must not honestly believe what he professes. Communists, in the McCarthy era, were so stigmatized. ${ }^{23}$ An institution might also attempt to proscribe by regulation certain teaching or writing, and then charge anyone who defied the ban with insubordination.

The only sector of higher education where one can find avowed denials of academic freedom is occupied by religiously controlled institutions that impose limitations they consider essential to the purity of their faith. Such limitations were tolerated by the 1940 Statement. In 1970 a set of interpretations formulated by the AAC and the AAUP asserted, perhaps prematurely, that " $[\mathrm{m}]$ ost church-related institutions no longer need or desire the departure from the principle of academic freedom implied in the 1940 Statement, and we do not now endorse such a departure."24 The interpreters did not foresee the recrudescence of Protestant and Moslem fundamentalisms, and the constraints on dissent imposed on Roman Catholic scholars in recent years. ${ }^{25}$ These religious limitations on academic freedom are dealt with elsewhere in this symposium ${ }^{26}$ and need not be elaborated here.

We return to the central issue of this article: does academic tenure reinforce academic freedom? As we have already asserted, of course it does. Allowing always for the human capacity to evade and distort punitive measures, and for the tendency of any system to become leaky under heavy pressures, a system that makes it difficult to penalize a speaker does indeed underwrite the speaker's freedom. ${ }^{27}$

Before going on to inquire whether tenure performs its intended function at too great a cost, let us offer a rapid look at the academic freedom scene as it appeared early in the century, in contrast to the seeming security that prevails toward the end of 1990. One has only to peruse the still standard work of 1955, The Development of Academic Freedom in the United States, by Richard Hofstadter and Walter Metzger, ${ }^{28}$ or other histories of higher education, to be reminded that, before 1915 , respected university presidents and boards of

23. See Sidney Hook, Should Communists be Permitted to Teach?, New York Times Magazine 7 (February 27, 1949). For rebuttal, compare Fritz Machlup, On Some Misconceptions Concerning Academic Freedom, 41 AAUP Bull 753 (1955).

24. 1990 AAUP Red Book at 6 (cited in note 11).

25. See Report: Academic Freedom and Tenure: Southeastern Baptist Theological Seminary (North Carolina), 75 Academe 35 (May-June 1989); Concordia Theological Seminary (Indiana), 75 Academe 57 (May-June 1989); Catholic University of America, 75 Academe 27 (September-October 1989).

26. Michael W. McConnell, Academic Freedom in Religious Colleges and Universities, 53 L \& Contemp Probs 303 (Summer 1990).

27. Without suppressing the status of the speaker, it is of course possible to infringe academic freedom by suppressing specific speech. Works of art, either dramatic or visual, are especially vulnerable to this kind of denial of freedom. See Robert M. O'Neil, Artistic Freedom and Academic Freedom, 53 L \& Contemp Probs 177 (Summer 1990); Paul Strohm, Academic Freedom and Artistic Expression, 76 Academe 7 (July-August 1990); Paul Strohm, Statement on Academic Freedom and Artistic Expression, 76 Academe 13 (July-August 1990). Such denials, however, ordinarily do not impinge on tenure.

28. Richard Hofstadter \& Walter P. Metzger, The Development of Academic Freedom in the United States 420-21 (Columbia Univ Press, 1955). 
trustees had little hesitation in firing senior professors who took positions on great issues of the day contrary to the conventional wisdom. Indeed, presidents themselves were not immune. ${ }^{29}$ Immediately after the seminal 1915 Declaration, our entry into World War I extinguished academic freedom for critics of the war; the AAUP itself joined in condoning dismissals for wartime disloyalty. ${ }^{30}$ Tenure, even if nominally recognized, apparently provided little protection.

For an oblique snapshot of the near impregnability that tenure has attained by 1990, we adduce as evidence two fierce books published in that year. Both are sharply critical of the damage that their authors think influential faculty are wreaking on higher education. Both conclude, though they do not accept, that nothing can be done to repress the malignants.

Page Smith, a prolific popular historian who fled academe in 1974, published a wide-ranging polemic, Killing the Spirit. ${ }^{31}$ Smith believes that higher education has gone so desperately astray from the ideals of the American Enlightenment, which flourished in a golden age at Johns Hopkins University roughly a century ago, ${ }^{32}$ that it is now dominated by presentism, excessive specialization, relativism, and giantism. ${ }^{33}$ He considers the greatest evils of the system to include the dominance of the Ph.D. and the institution of tenure. ${ }^{34}$ Repeatedly he blames tenured faculty for what he considers the current perversions of the humanities, ${ }^{35}$ the social sciences, ${ }^{36}$ and the curriculum, ${ }^{37}$ reserving special disdain for women's studies. ${ }^{38}$ In the end, he can only ask, "Can a more humane and sensible system of tenure be worked out? Or should the whole system be abandoned?" 39 The other recent polemic, Tenured Radicals, by Roger Kimball, ${ }^{40}$ is thinner and shriller than Killing the Spirit. ${ }^{41}$ It concentrates on the invasion of academic letters by women's studies, black studies, gay studies, deconstruction, poststructuralism, and so on. ${ }^{42}$ Kimball dislikes everything he sees. The only reference to tenure is in the title; it is apparently significant to Kimball that the radicals pushing these abominations are tenured. The point for our purposes is that both authors seem to accept that their enemies are immovable. Tenure does

\footnotetext{
29. Id.

30. Id at 504

31. Smith, Killing the Spirit (cited in note 17).

32. Id at $\mathbf{5 4 - 5 5}$.

33. Id at 294.

34. Id at $108 \mathrm{ff}$.

35. Id at $253 \mathrm{ff}$.

36. Id at $223 \mathrm{ff}$.

37. Id at $140 \mathrm{ff}$.

38. Id at $285 \mathrm{ff}$.

39. Id at 304 .

40. Roger Kimball, Tenured Radicals: How Politics Has Corrupted Our Higher Education (Harper \& Row, 1990) ("Tenured Radicals").

41. Smith, Killing the Spiril (cited in note 17).

42. Kimball, Tenured Radicals at xi-xviii (cited in note 40).
} 
protect academic freedom, even when that freedom is accused of being put to bad purposes. ${ }^{43}$

\section{III}

\section{The Costs of Tenure}

Quite aside from the possibility that the wrong people may have tenure, the conferral of tenure certainly entails costs-for the institution, for the recipient, and for society. For the institution, the first cost is the long-term financial commitment. If we assume a thirty-five year duration of tenure until a normal retirement age, with annual compensation starting at $\$ 40,000$ (and sure to increase with time and inflation), the employing institution incurs a commitment that will doubtless reach two million dollars.

The second and more troubling cost (one that will be borne, directly or indirectly, by all the participants) arises from the risk that the tenure decision will turn out to have been unwise. The teacher may not teach well; the scholar may not publish; the university may have acquired a poor citizen. All these shortfalls are expectable, in every possible combination. Note that these risks are present despite the long probationary period. If the full seven year period allowed by the 1940 Statement is taken (or even an extra two or three years in certain prestigious and cautious universities), the candidate will have been thoroughly scrutinized and appraised. Because of the magnitude of the commitment, anxious judgment will have been applied, surely by the administration, even if the candidate's department is careless, or overeager to retain a colleague. There are few counterparts to this long apprenticeship, which, one should remember, commences only when the teacher has completed or almost completed his formal schooling. The medical postdoctoral ordeal of internship and residency can stretch almost as long. The time to make (or not make) partner in a large law firm is also comparable. Contrast the attainment of civil service tenure by a bureaucrat, a police officer, or a teacher. That process will rarely require more than three years.

Thus, the decision-makers will have made every effort to satisfy themselves of a candidate's worth; but their judgments may turn out to have been misjudgments. If so, we will eventually confront the universal cliché-that the university is spotted, or even riddled, with deadwood.

Why this particular metaphor? After all, as Metzger has tartly observed, the university is not a lumber warehouse. ${ }^{44}$ One would welcome a lexicographer's search to learn how it started. Without waiting for that enterprise, we must confront the denigration.

Perhaps the prevalence of deadwood is assumed because of the conceded difficulty of removing a tenured professor. It is also difficult to remove a laggard civil servant, and complaints about the efficiency of the government's

43. The authors take no position on the validity of the indictments brought by Smith and Kimball. Their works are relevant for us only as testimonies to the strength of tenure.

44. Metzger, Academic Tenure at 159 (cited in note 6). 
many branches are not unfamiliar. But the contemplation of faculty deadwood seems to arouse special emotions. Is this because the claims for academic tenure, and our concern with protecting academic freedom, are viewed as overblown? After all, how many tenured faculty members face threats to their freedom during their careers? There is no evidence that many of those tenured have more than fleeting brushes with hostile authorities, be they colleagues, administrators, or outsiders who are in positions of power.

The usual rejoinder to this observation is that all must be protected for the sake of the occasional heretic from whose heresies we learn something. Who in academic life is going to make dangerous contributions to learning? There is no way to know in advance. Therefore everyone, the timeserver as well as the prophetic genius, should have the opportunity to qualify for the shelter of tenure. Unsettling genius may bloom late.

All the handwringing over deadwood is itself remarkably devoid of anything resembling data about the extent of the blight. The present writers have been paying attention for thirty years to controversies about the value of tenure; they cannot recall ever seeing anything resembling a statistic. In fact, the only numerical estimate that they can summon is from Dean Rosovsky's genial appraisal of tenure, based chiefly on his long experience at Harvard. He opines that "the label deadwood would apply only to under 2 percent of a major university faculty; that is my totally unscientific conclusion." 45 If that is a plausible guess, how many more could be labelled deadwood at universities and four-year colleges that make less demanding requirements for tenure? Might we guess 5 percent? The issue whether any small number, 2 percent or 5 percent, justifies undoing the tenure system leads to further questions. What is the deadwood index for comparable sectors of the workforce? What sectors are comparable? Do these sectors have de facto tenure, in that, after a certain period of employment, stability is expected and achieved? Is the detriment to society from the existence of unpruned deadwood among civil servants, accountants, bankers, or lawyers (to pick examples almost at random) more or less severe than the harm caused by sloth among tenured academics? ${ }^{46}$ Such questions are rarely asked, let alone answered. It would be so difficult to make effective inquiries that their absence is understandable.

Thus far we have established two conclusions. First, tenure does safeguard academic freedom. Second, it does so at a cost, in the occasional case when a tenured scholar becomes deadwood, yet does not function so poorly as to warrant removal. The academic enterprise in that case is not getting its money's worth, especially when deserving candidates are available for the poorly filled position. It is perhaps comforting to think that in the absence of a tenure system, substandard performers would be more easily separated. But there is surely a countervailing costly risk that, without the up-

45. Rosovsky, The University at 210-11 (cited in note 20).

46. An engaging impressionistic survey of the prevalence of de facto tenure in many walks of life is to be found in John R. Silber, Tenure in Context, in Bardwell L. Smith \& Associates, eds, The Tenure Debate at 34-42 (cited in note 20). 
or-out decision that is crucial to conferring or denying tenure, marginal performers would simply be allowed to linger on and on until retirement.

There is yet another cost, which is imposed upon scholars who do become tenured. Tenured stability is conventionally supported as a tradeoff for the lower salaries paid to faculty members, compared to other highly trained professionals. But as Fritz Machlup showed in a pioneering examination of tenure as viewed by an economist, those lower salaries should also be viewed as a cost. ${ }^{47}$ Without tenure, the uncertainty of employment would require higher salaries.

\section{IV}

\section{Other Gains from Tenure That Offset the Costs}

Conceding social and economic loss from those who attain tenure and then perform submarginally, are there other offsetting gains from the practice?

We have already mentioned economic security; tenured faculty members accept low wages in return for appointment until retirement. The emphasis on security in the 1940 Statement ("Freedom and economic security, hence tenure, are indispensable . . . .") represents, according to Metzger, a "routinization of job security that might have been picked up from Civil Service situations." 48 One might guess that the experience of the Great Depression, not entirely dispelled, might also have influenced the drafters of 1940. If the AAUP were writing the 1940 Statement in 1990 , we doubt that economic security would be given parity with academic freedom as the raison d'etre of tenure. Faculty salaries, we suggest, should be equivalent to average earnings in comparable professions. This seems a more worthy goal than keeping academics one step ahead of shabby gentility.

However, long-term employment stability represents an important benefit of tenure, quite aside from the assurance of a salary. The assurance that one can get on with one's work without much interference, that one has status in a company of learned men and women, that one can grow old without fearing the axe of age discrimination (now illegal but surely still wielded)-all these are advantages of tenure. They are what Rosovsky aptly calls "tenure as social contract." 49 The social contract aspects of tenure must also create a favorable climate for academic freedom (except when the contract is broken, and colleagues become enemies). Similarly, the extended duration of a tenured

47. Machlup, 50 AAUP Bull at 118 (cited in note 20)

48. Metzger, Academic Tenure at 152 (cited in note 6).

49. Rosovsky, The University at 183 (cited in note 20). A similar view is well expressed by Bowen and Schuster. They write that tenure

is conducive to collegiality. A college or university to be maximally effective must be a community to which people belong and which they care about ... . Such collegiality is not created instantly or spontaneously. It is developed over time through the presence of committed faculties. Tenure is a powerful tool for enlisting that commitment.

Bowen \& Schuster, American Professors at 236-37 (cited in note 21). 
appointment aids academic freedom in that it makes possible commitments to very long-term projects. ${ }^{50}$

Leaving academic freedom considerations aside, McPherson and Winston show in a valuable paper that " $[\mathrm{t}]$ he tenure institution has some desirable efficiency properties that are often overlooked." 51 Stable employment, they point out, promotes efficiency by diminishing uncertainty. Academic employment differs from business employment in that the corporation is free to move people around and shift their fields. On the other hand, faculty members are trained to rather intense specialization. Their capacities can be measured only by their professional peers. Once that has been done during the long probationary period, and the tenure decision has been reached, further continuous monitoring is usually unnecessary. Such monitoring takes up very heavy resources in business enterprises. It would be especially costly for academic institutions if attempted by inexpert central administrations. Because of their own tenure, the senior professors who in practice make the tenure decision are not threatened by bringing on able colleagues. This fact helps to maintain quality. Indeed, a cynical-seeming paper by Lorne Carmichael argues that tenure is essential to prevent declines in quality. "Loosely, tenure is necessary because without it incumbents would never be willing to hire people who might turn out to be better than themselves," Carmichael asserts. ${ }^{52}$

Still another variant on the economic arguments describes the university as a principal in a frequent business pattern called "hands-tying." In dealing with promising researchers, the university induces them with tenure. That is, the university ties its hands so that it cannot renege just because a particular appointment does not pan out. If it selects shrewdly, it will, on balance, gain, and able scholars will sign on because of the tenure commitment. ${ }^{53}$

Since much of the opposition to tenure decries its supposed inefficiency (because of the deadwood risk), it is reassuring to have economists, habituated as they are to following through all the implications of a problem, emerging with efficiency rationales for tenure. Of course, none of the arguments we have advanced is amenable to quantification. We have pointed out familiar, indeed obvious, reasons why tenure supports academic freedom. We have conceded that tenure does impose some costs on society, universities, and teachers, while arguing that deadwood costs are unknown and probably exaggerated. We then described benefits of tenure independent of the central theme of academic freedom. The reader must strike her own balance.

50. Brewster, 58 AAUP Bull at 382 (cited in note 1).

51. Michael McPherson \& Gordon C. Winston, The Economics of Academic Tenure: A Relational Perspective, $4 \mathrm{~J}$ Econ Behavior \& Org 163 (1983).

52. H. Lorne Carmichael, Incentives in Academics: Why Is There Tenure?, $96 \mathrm{~J}$ Pol Econ 453, 454 (1988).

53. Henry Hansmann \& Reinier Kraakman, Hands-Tying in Principal-Agent Relationships: Venture Capital Financing, Publishing Contracts, and Academic Tenure 26 (December 1989) (unpublished manuscript, on file with authors). 


\section{Alternatives to Tenure}

Critics propose four possible alternatives to tenure, all of which are advocated as safeguarding academic freedom. The first alternative advanced is that of legal tribunals, affording both procedural and substantive due process; supporters argue these protections would make conventional tenure unnecessary. The second, related to the first, would rely on internal university tribunals. The third and fourth, almost interchangeable in their advantages and disadvantages, are "term tenure"-successive term appointments, of five years or more, until retirement-and "interruptible tenure"-periodic formal review that can lead to a termination of tenure.

\section{A. Reliance on the Law}

The disputants who blithely declare that academics do not need tenure because the courts will protect academic freedom are not relying on close analysis of the relevant case law. ${ }^{54}$ The first and fourteenth amendments do offer some aid to injured professors; but the scope of protection is hardly sufficient to supplant the safeguards of contractual or statutory tenure.

Although several ringing affirmations of academic freedom have emanated from the Supreme Court, it is still uncertain what that Court would do in a straightforward case in which an untenured professor has been disciplined for the content of classroom utterances or scholarly writing. A first obstacle arises from the proposition that the academic freedom extolled by the Court is that of the institution, not of individual faculty members. ${ }^{55}$ The terrain is too extensive to be retravelled here. ${ }^{56}$ Consider only Justice Frankfurter's famous dictum in his concurrence to Sweezy $v$. New Hampshire, ${ }^{57}$ where he quoted South African academics on "[t]he four essential freedoms of $a$ university-to determine for itself on academic grounds who may teach, what may be taught, how it shall be taught, and who may be admitted to study." 58

54. See James O'Toole, Tenure: A Conscientious Objection, Change 24, 29 (June-July 1978). This article is a relatively sustained denunciation and renunciation (by its author) of tenure. It was responded to by William W. Van Alstyne, Tenure: $A$ Conscientious Objective, 10 Change 44 (October 1978); compare the remark of an unnamed "official of an educational institution" in Malcolm G. Scully, Attacks on Tenure Mount at 15 (cited in note 15): "As I see it, academic freedom is just another phrase for constitutional rights, properly understood."

55. This thesis is well developed in J. Peter Byrne, Academic Freedom: $A$ "Special Concern of the First Amendment," 99 Yale L J 251 (1989). Compare Walter P. Metzger, Profession and Constitution: Two Definitions of Academic Freedom in America, 66 Tex L Rev 1265 (1988) (similar approach); Matthew W. Finkin, On "Institutional" Academic Freedom, 61 Tex L Rev 817 (1983); William W. Van Alstyne, The Specific Theory of Academic Freedom and the General Issue of Civil Liberties, 404 Annals Am Acad Pol Soc Sci 140 (November 1972).

56. See David M. Rabban, A Functional Analysis of "Individual" and "Institutional" Academic Freedom Under the First Amendment, 53 L \& Contemp Probs 227 (Summer 1990); William W. Van Alstyne, Academic Freedom and the First Amendment in the Supreme Court of The United States: An Unhurried Review, 53 L \& Contemp Probs 79 (Summer 1990).

57. 354 US 236, 263 (1957).

58. Id (emphasis added). 
Other pronouncements by members of the Court similarly, deal with institutional freedom rather than that of individuals. ${ }^{59}$

Two lower-court decisions do bring the first amendment into the classroom. One, Cooper v. Ross, ${ }^{60}$ is quite remarkable. Judge Heaney of the Eighth Circuit, sitting as a district judge, found that the plaintiff had been denied reappointment at the University of Arkansas at Little Rock because he had made known in his classes and elsewhere that he was a communist, a member of the Progressive Labor party. These disclosures had inflamed many members of the legislature. Apparently without any difficulty, Judge Heaney wrote,

[i]n summary, the Court concludes that Cooper's membership in the PLP and his public acknowledgement of his beliefs, both inside and outside the University classroom, were protected conduct under the First and Fourteenth Amendments. The Court finds that this protected activity was a substantial or motivating factor in the University's decision not to reappoint Cooper. ${ }^{61}$

Another decision encouraging the view that courts will protect the academic freedom of the untenured is Dube v. State University of New York. ${ }^{62}$ In this recent case, the Second Circuit held that Professor Ernest Dube was entitled to a trial on his allegations that the State University of New York denied him tenure in retaliation against what some perceived to be his suggestions (made in a seminar) that there are racist strains in Zionism. Dube's alleged heresies aroused the ire of many Jewish persons and groups, with Governor Mario Cuomo joining in a sharp expression of concern. ${ }^{63}$ The court agreed that Dube's first amendment rights might have been impaired. ${ }^{64}$ This case was complicated by issues of qualified immunity of state officials, who by virtue of the eleventh amendment enjoy considerable protection against suit. These issues led the other two members of the panel to write separate concurring opinions, ${ }^{65}$ but were apparently not even raised in Cooper.

59. Consider especially the slighting reference by Justice Blackmun (writing for a unanimous Court) to "the so-called academic freedom cases." University of Pennsylvania v EEOC, $110 \mathrm{~S} \mathrm{Ct}$ 577, 586 (1990). This case denied any academic freedom privilege for the University to protect peer review materials from disclosure to the Equal Employment Opportunity Commission on behalf of a plaintiff claiming race and sex discrimination. However, the Court went on to say, "Fortunately, we need not define today the precise contours of any academic freedom right against government attempts to influence the content of academic speech ...". Id. A footnote went farther:

Obvious First Amendment problems would arise where government attempts to direct the content of speech at private universities. Such content-based regulation of private speech traditionally has carried with it a heavy burden of justification. Where, as was the situation in the academic-freedom cases, government attempts to direct the content of speech at public educational institutions, complicated First Amendment issues are presented because government is simultaneously both speaker and regulator.

Id at $587 \mathrm{n} 10$ (citations omitted).

60. 472 F Supp 802 (ED Ark 1979).

61. Id at 814 .

62. 900 F2d 587 (2d Cir 1990).

63. Id at 590 .

64. Id at 597.

65. Id at 600 (Miner concurring; Mahoney generally concurring). 
It would take this article far afield if it did any more than to note their existence. ${ }^{66}$

Thus, we find some support for faculty members in these two instances of alleged or actual invasions of academic freedom in the classroom. Similarly, university professors have fared well when subjected to discipline for critical statements directed at colleagues or administrators. ${ }^{67}$

The constitutional standards that apply here come from a quartet of Supreme Court decisions that focus not on the academy, but on general standards of critical speech by public employees. In two of the four cases, teachers were plaintiffs. The wellspring of this little fountain of constitutional law is Pickering $v$. Board of Education, ${ }^{68}$ which held, with respect to a high school teacher who wrote a letter to the local newspaper criticizing the handling of a bond issue for new schools, that the Board of Education could not fire him unless his critical statements were knowingly or recklessly false, which the Court said they were not. ${ }^{69}$ The Court did, however, recognize an "interest of the State, as an employer, in promoting the efficiency of the public services it performs through its employees."'70 A balance had to be struck. That balance was tilted somewhat against the employee fifteen years later in Connick $v$. Myers, ${ }^{71}$ where an assistant district attorney was fired for distributing a slanted "questionnaire" to her colleagues. The Court found that "Myers' questionnaire touched upon matters of public concern in only a most limited sense."72 It could be "most accurately characterized as an employee grievance concerning internal office policy."7s The balance tilted again toward the employee in the bizarre case of Rankin v. McPherson. ${ }^{74}$ Rankin concerned an incautious remark by a clerk in a county constable's office, following the 1981 attempt to assassinate President Reagan: "If they go for him again, I hope they get him." 75 The Court held this statement not to warrant her dismissal. ${ }^{76}$ (Both Connick and McPherson were 5-4 decisions.)

The fourth player in the quartet of Supreme Court decisions is Mt. Healthy City School District Board of Education v. Doyle. ${ }^{77}$ In that case, the Court held that

66. Summarily, the officials would have qualified immunity from damages if their conduct did not violate "clearly established statutory or constitutional rights of which a reasonable person would have known." Id at 596, quoting Harlow v Fitzgerald, 457 US 800, 818 (1982). But, Judge Meskill wrote, the conduct alleged, if established at trial, would violate "long-standing and clearly established First Amendment law." Id at 597. Dube, however, showed no 14th amendment due process violations, because Board of Regents v Roth, 408 US 564 (1972), controlled. 900 F2d at 599.

67. See notes $82-88$ and accompanying text.

68. 391 US $563(1968)$.

69. Id at 574. The Pickering court borrowed the "knowingly or recklessly false" yardstick as a limit for protection of plaintiff's speech from New York Times v Sullivan, 376 US 254 (1964) (the famous case narrowing libel recovery by public officials).

70. 391 US at 568 .

71. 461 US 138 (1983).

72. Id at 154 .

73. Id.

74. 483 US 378 (1987).

75. Id at 380 .

76. Id at 383 .

77. 429 US 274 (1977). 
a school teacher who instigated over-the-air critical comments about the school's principal could claim Pickering protection when he was not reappointed. ${ }^{78}$ The teacher would have the burden of showing that protected speech was a "motivating" or "substantial" factor in the board's adverse decision. ${ }^{79}$ But then, the Court held unanimously, the board need only show by a preponderance of the evidence that it had other adequate grounds for a dismissal. ${ }^{80}$ On remand, the district court so found, and this outcome was affirmed. ${ }^{81} \mathrm{Mt}$. Healthy's reach is not confined to cases arising from critical statements. Rather, Mt. Healthy's standard will surely be involved if the Dube case goes to trial, because the announced ground for the denial of tenure was Dube's very modest scholarly production.

The balancing act called for by Pickering, Connick, and Rankin has been applied to the advantage of both tenured and nontenured professors. In Kurtz $v$. Vickrey, ${ }^{82}$ a tenured associate professor, whose carping clearly overtried the patience of the defendant president, escaped summary judgment against him because the reviewing court found some of his criticisms sufficiently related to matters of public concern. ${ }^{83}$ The issue here was not dismissal; instead, it was Kurtz's demand for promotion to the rank of professor. ${ }^{84}$ At trial, Kurtz would still face the Mt. Healthy standard and the university's claim that his scholarly activity was deficient. ${ }^{85}$

Even more remarkable was the application of Pickering in Johnson v. Lincoln University ${ }^{86}$ to reverse a summary judgment and gain a judicial hearing for a tenured faculty member who was dismissed on a variety of charges, some of which the court found to stem from his criticisms on matters of public concern. ${ }^{87}$ The court found no want of due process in the internal removal. It went straight to the first amendment challenges. ${ }^{88}$

Absent an unfavorable disposition in the Supreme Court that derails the momentum in the courts of appeal, it appears that direct resort to the first amendment in support of claims of denials of academic freedom ${ }^{89}$ has a brightening future. Mt. Healthy, however, always casts an overhanging shadow, for it practically invites censorious administrations to dredge up

78. Id at 284 .

79. Id at 287.

80. Id.

81. Doyle v Mt. Healthy City School District, 670 F2d 59,61 (6th Cir 1982), aff'g decision of US Dist

Ct (SD Ohio) after remand (unpubl opinion).

82. 855 F2d 723 (11th Cir 1988).

83. Id at $733-34$.

84. Id at 725 .

85. Id at 734 .

86. 776 F2d 443 (3d Cir 1985).

87. Id at 451-53.

88. Id at 449-50, 455. This was part of deep troubles at Lincoln that had supposedly been resolved by a consent decree. Id at 448. See Trotman $v$ Board of Trustees of Lincoln University, 635 F2d 216 (3d Cir 1980). See also D'Andrea v Adams, 626 F2d 469 (5th Cir 1980) (another successful invocation of Pickering by a tenured faculty member).

89. The almost invariable jurisdictional basis for actions against state officials in any of the cases discussed here is by way of the Civil Rights Act of 1871, 42 USC $\S 1983 ; 28$ USC $\S \S 1343(3)$, (4) (1979). 
other deficiencies of a professor facing discipline, so as to be able to say, "We would have fired her anyway." Indeed, a capable administrator, even though bothered beyond endurance by a troublemaker, as in Kurtz, or buffeted by outside powers, will try to avoid offering up the victim's head on a first amendment platter. Such an administrator does not need the nudge of $M t$. Healthy to search for adequate independent grounds that will support adverse action.

Now tenure does make a difference. The untenured faculty member, who needs a hearing in order to challenge the adequacy of asserted grounds for termination, will find that the Constitution does not entitle her to a hearing. For that matter, she has no legal right to know why she is being fired. This state of affairs is the result of the well-known 1972 decision of the Supreme Court in Board of Regents of State Colleges v. Roth. ${ }^{90}$ In Roth, Justice Stewart pointed out that, to claim due process under the fourteenth amendment, Roth had to have either a property interest or a liberty interest.91 As a term appointee whose term had expired, he had neither. ${ }^{92}$ The university need say nothing; Roth's contract was at an end. ${ }^{93}$ Roth is usually bracketed with Perry v. Sindermann ${ }^{94}$ decided along with Roth, and pointedly connected for our purpose. Sindermann claimed he had been let go because of his lawful political activities. His college had no formal tenure system; but the Court, by an indulgent interpretation of a pompously phrased but ambivalent college statement on job security that could equally have been taken to negate tenure, concluded that Sindermann must be given an opportunity to show that he had acquired tenure in his ten years of teaching (albeit at three different institutions) through an "unwritten 'common law'."95

Both cases make it clear that the property or liberty entitlements that would activate fourteenth amendment due process must ordinarily come from outside the Constitution-from common law, contract, or statute..$^{96}$ This proposition remains unchallenged. While the professor has the burden of proving that he has tenure or its equivalent, once he has it, the core legal meaning of tenure comes to bear: the burden of proof is then on the institution to establish valid grounds for discipline. In any case, therefore,

\footnotetext{
90. 408 US 564 (1972).

91. Id at 570-71

92. Id at $\mathbf{5 7 8}$.

93. Id.

94. 408 US 593 (1972).

95. 408 US at $602-03$. Sindermann ultimately accepted a substantial settlement. The policy statement read as follows:

Teacher Tenure: Odessa College has no tenure system. The Administration of the College wishes the faculty member to feel that he has permanent tenure as long as his teaching services are satisfactory and as long as he displays a cooperative attitude toward his coworkers and his superiors, and as long as he is happy in his work. Id at 600 .

96. 408 US at 577. Commentary on Roth and Sindermann is extensive. See, for example, Peter N. Simon, Liberty and Property in the Supreme Court: A Defense of Roth and Perry, 71 Cal L Rev 146 (1983); William W. Van Alstyne, Cracks in "The New Property": Adjudicative Due Process in the Administrative State, 62 Cornell L Rev 445 (1977).
} 
where the academic freedom elements are masked, ambiguous, or indirect, tenure matters a great deal.

One can also boldly imagine a transformation of our legal system so that it would offer comprehensive relief for persons deprived of their academic freedom, relief free of such roadblocks as the necessity to show state action in order to gain shelter under the Constitution. The state action requirement effectively leaves unprotected teachers at private institutions, who still represent one-fourth of the total scene. ${ }^{97}$

Such a transformation is not entirely imaginary. In the United Kingdom, when a 1988 Act of Parliament set about to abolish tenure for the future, outcries in defense of academic freedom were raised, especially in the House of Lords. This far-reaching legislation included a stirring declaration that directed the five university commissioners who would henceforth rule the academic roost to "ensure that academic staff have freedom within the law to question and test received wisdom, and to put forward new ideas and controversial or unpopular opinions, without placing themselves in jeopardy of losing their jobs or privileges that they may have at their institutions." 98

Government ministers opposing this soothing generality argued that it would not be "justiciable." 99 It is not beyond the capacity of the British courts either to make the new charter toothsome or to render it toothless. Such transatlantic surmise would be premature. In any case, for our Congress and legislatures, a measure of this sort is at present beyond imagining. Consequently, unless it is buttressed by tenure, the realm of law outside the university provides an imperfect protection for academic freedom. ${ }^{100}$

\section{B. Internal Tribunals}

We next ask whether internal tribunals, if they afforded a full panoply of due process guarantees, would or could provide justice for aggrieved professors, without any system of tenure as we now know it. That such tribunals might suffice has been suggested both by Dean Henry Rosovsky of Harvard, a friend of tenure, and by President John Silber of Boston University, assuredly not a friend of tenure. ${ }^{101}$ Neither they, nor any other commentator we are aware of, has fleshed out this suggestion, which bristles with both possibilities and problems.

97. Although there is no reason why state courts cannot serve the private sector by recognizing academic freedom rights in state constitutions. These problems are succinctly addressed in Byrne, 99 Yale L J at 299, 327 (cited in note 55).

98. Education Reform Act, Ch 40, § 202(2)(a) (1988).

99. See Ekkehard Kopp, Higher Education (Not Yet Post-Thatcher) in the United Kingdom, 74 Academe 67, 69 (September-October 1988). Attempts to end tenure in Australia and New Zealand have been rebuffed. In Australia, there is currently a fitful move to enact an academic freedom statute (conversations with Ann H. Franke, Esq., scholar in residence 1990-91 at Bond University, the first private university in Australia).

100. We have perhaps failed to emphasize the uncertainties, and the attendant stress, expense, and delay, that are built into the trial and appellate process.

101. Rosovsky's suggestion is at the end of a footnote to his supportive discussion of tenure. Rosovsky, The University at $181 \mathrm{n} 7$ (cited in note 20). Silber's comes from a journalist's survey. Scully, Attacks on Tenure Mount at 1, 4 (cited in note 15). 
First, what would be the structure of academic appointments? Would they be for one-year terms only? State law nominally compels annual contracts at many public institutions, but such institutions have the backup of tenure and often of de facto multiyear term appointments for probationers.

Try another no-tenure scenario. Assume that all appointments were indefinite in duration, and went on year-to-year unless terminated. Could they be terminated at the employer's will, except when the teacher prevailed on a claim of infringement of academic freedom (or, though it is not our topic, of unlawful discrimination)? Employment at will is no longer tolerable in large sectors of the labor market; we doubt that most players in the academic marketplace would accept a regime that gave no job security except for a one-year period. That regime is what teachers off the tenure track endure now, to scarcely anyone's satisfaction.

In a due process, no-tenure world, the missing element is not procedural due process but the substance on which it would act in a disputed dismissal. If something resembling adequate cause is the basis for termination, we quickly arrive at the critical question: does the employer have the burden of establishing adequate cause, whatever its content, or must the imperilled teacher establish its absence? If the former, we are back to the key element of a tenure status! And, what is probably not desired by those who want to substitute internal due process for tenure, the burden on the administration to demonstrate cause would also protect those who are now considered probationers, unless we re-created that lower status as well.

If a threatened teacher has the burden of proving that her performance met prevailing standards, would the injection of an academic freedom issue then shift the burden again as to that issue? Could the teacher simply assert a violation, or would she first have to establish a prima facie case? That is what AAUP standards now require a nontenured faculty member to do if she is not reappointed and alleges that the decision was based on considerations that violate her academic freedom. ${ }^{102}$

There simply is no direct experience, and too little comparable experience, to reach any comfortable prediction about the adequacy of a dueprocess-only regime. Evergreen State College and Hampshire College, two small progressive colleges, have experimented with a system of no tenure, coupled with intricate due process protections in academic freedom cases. These colleges have not, so far as we know, had occasion to process a case all the way through their complicated procedures.

Richard Chait and Andrew Ford, who paid close attention to Evergreen and Hampshire in their 1982 study, asserted that "the fact remains that

102. Although Regulation 10 of the AAUP Recommended Institutional Regulations on Academic Freedom and Tenure does not so specify, it is presumably the hearing committee that decides whether a prima facie case has been made. AAUP, Recommended Institutional Regulations, in 1990 AAUP Red Book at 21, 28 (cited in note 11) ("RIR"). Once that crevasse is bridged, the administration must then "come forward with evidence in support of [its] decision." Id. But the burden of proof still "rest[s] upon the faculty member." Id. 
academic freedom can survive apart from tenure and together with term contracts." 103 No doubt it can survive, with high-minded people in charge, but will it survive when exposed to less tender mercies? The central difficulty lies in the expectable failure of academic freedom issues to present themselves with their prima facie dress already properly adjusted. The real world is filled rather with ambiguity, rationalization, and subterfuge. Ambiguity: was the nonrentention of Professor $X$, who believes that the Holocaust never happened, really a case of academic freedom at all? Rationalization: his bizarre views aside, Professor $X$ is in fact not a good teacher. Subterfuge: Professor X's views are causing alumni to stop contributing, but we don't have to say so; we can devise another reason for nonretention.

This large gray area is what causes the writers to want to know more about the context of employment security in which an internal due process model would operate, if such a system's guarantees were confined to academic freedom cases.

\section{C. "Term Tenure" and "Interruptible Tenure"}

The third and fourth alternatives to tenure are schemes for what may be called "term tenure" or "interruptible tenure." By "term tenure," we mean the substitution of a series of fairly long term appointments-say five or seven years-with no assurance of continuation; "tenure" is here misapplied, because one would have the protections of tenure only during a given term. Term tenure surely takes its place among the oxymora that confuse thought. Tenure means indefinite employment terminable only for cause (or for certain specified constraints such as financial exigency). Term tenure is not tenure, and does little to protect academic freedom. Moreover, reappointment decision-making under term tenure is burdensome, a failing shared by interruptible tenure.

By "interruptible" tenure we mean a system that purports to confer tenure, and then, at intervals of five or possibly ten years, conducts a periodic review of the tenured professor's performance. If the outcome of this review is unsatisfactory, it can result in dismissal. Periodic reviews of varying intensity are a frequently prescribed nostrum for the deficiencies of the professoriate. $^{104}$ Most such proposals are put forward as tools for faculty development. If they are routinely required, they generate a great deal of paperwork and take up a great deal of time and energy for the colleagues, chairs, deans, and provosts who must do the reviewing. ${ }^{105}$ The benefits are uncertain enough that the idea has not widely taken hold.

103. Richard P. Chait \& Andrew T. Ford, Beyond Traditional Tenure 58 (Jossey-Bass, 1982).

104. For example, Martin Bronfenbrenner, Toward Compromise on Tenure, 5 Atlantic Econ J 22 (March 1977); Ernst Mayr, Tenure: A Sacred Cow?, 199 Science 1293 (March 1978).

105. Committee $A$ has reported that:

The University of Colorado initiated a systematic program of post-tenure review [in 1983], and a thorough study of the fruits of that program-apparently the first such study-was undertaken and published in 1989. The study, prepared by Associate Vice President for 
By way of contrast, in the Wingspread Conference on Evaluation of Tenured Faculty in 1983, the participants (who included the present writers and a substantial number of senior university officers) delineated with approval the manifold formal and informal evaluations that take place all the time. ${ }^{106}$ Going far beyond these models are suggestions that performance reviews may lead to termination. The 1983 Conference consensus statement deprecated the use of either systematic or informal evaluations as a ground for dismissal: "Where grounds for dismissal are believed to exist, informal resolutions of the problem should be pursued first. If these fail, then existing due process procedures can be employed." 107

In the keynote address for that conference, Harold Shapiro, then president of the University of Michigan and later of Princeton, offered a concise and eloquent appraisal of tenure. While cautiously endorsing "periodic evaluation of tenured faculty [as] simply good personnel policy," 108 he warns that

we should disconnect such ongoing periodic evaluations from the question of tenure itself. Any attempt to link the issue of tenure and periodic evaluation of tenured faculty, no matter how well-meaning, is, in my judgment, unlikely to strengthen our institutions .... To the extent that the present tenure system serves society well, it does so independent of periodic evaluation. To the extent that the present system does not serve society well, a system of periodic posttenure evaluation linked to tenure itself will not rectify the situation. ${ }^{109}$

We will conclude this survey of alternatives to tenure with the "confession" of the authors of Beyond Traditional Tenure, the most extensive survey of the subject (although it does not include judicial protections). Chait and Ford wrote:

When we first decided to examine alternatives to traditional tenure policies, we assumed, at least tacitly, that we would discover one or several alternatives superior to tenure. We had heard too many criticisms of tenure and read too many indictments to believe that there were not more attractive alternatives. We would discover, analyze, and report these options; as a result, some colleges would abandon tenure. In turn, we would win a niche in academe as dragon slayers.

We were mistaken. The more we examined the alternatives, the less we were persuaded that any were markedly superior to tenure or irresistibly attractive. Instead, we reached essentially the same conclusion as the Keast Commission: effectively administered by a campus community, academic tenure can be an effective policy. ${ }^{110}$

Academic Affairs Marianne Wesson and Director of Policy and Planning Sandra Johnson, supports the conclusion that the benefits to be gained from such review are modest or speculative while the costs, principally consumption of time, are substantial and demonstrable.

Report of Commiltee A, 76 Academe 32, 38 (September-October 1990).

106. Statement of the Wingspread Conference on Evaluation of Tenured Faculty, 69 Academe 14a (November-December 1983).

107. Id.

108. Harry Shapiro, The Privilege and the Responsibility: Some Reflections on the Nature, Function, and Future of Academic Tenure, in Report on Periodic Evaluation of Tenured Faculty: A Discussion at Wingspread: August 24-26, 1983, 69 Academe la, 3a, 7a (November-December 1983).

109. Id.

110. Chait \& Ford, Beyond Traditional Tenure at 143 (cited in note 103). 
Leaks in the Dike: Weaknesses in the Safeguard of Tenure

Before turning to the problems of the untenured, we conclude this segment of our examination of tenure and academic freedom by looking at four characteristics of the system that may weaken it. These characteristics are, first, the adequacy of due process for professors threatened with dismissal; second, the possible abuse of financial exigency as a ground for termination; third, the risk that program changes will be used as a ground for termination; and, fourth, the concern that the end of mandatory retirement will somehow make tenure insupportable.

The suggestion that it might be too easy to fire a tenured professor would surely provoke nothing but derision among most administrators. Just the opposite view is imbedded in the conventional wisdom of academe. But firing a tenured professor is possible; it happens several times each year. ${ }^{111}$ It is meant to be difficult; otherwise the high threshold of adequate cause, and the allocation of the burden of proof to those who bring charges, would not have been called into being.

There is no way of knowing how many tenured faculty members, faced with implicit or explicit threats of dismissal for cause, simply go away quietly. As in the outside world, they take early retirement; they leave "to pursue other interests"; they are handed on to a less demanding institution. There are also stratagems of varying legitimacy. Departure may be purchaseable; poor working conditions, such as unwanted teaching assignments or cramped research space, can be pushed from the unpleasant to the intolerable. Ostracism by one's colleagues is not unheard of.

The disputed cases that attract attention, either through the press, through condemnation by means of an AAUP censure, or through a professor's resort to the courts, seem to fall loosely into three categories. In the first category are genuine invasions of freedom to teach or publish. These, we believe, would usually be exposed and repudiated by a fair hearing. They come most often to the AAUP's attention from institutions that neither recognize tenure nor afford fair procedures. ${ }^{112}$ The second category involves situations where there is a genuine difference of opinion whether the conduct charged deserves dismissal. Presumably, the professors who went to the

111. For an instructive example of a hard-fought case in which the former chair of the Department of Afro-American and African Studies was dismissed on wide-ranging charges of incompetent performance, see King $v$ University of Minnesota, 774 F2d 224 (8th Cir 1985). See also Mueller $v$ Regents of the University of Minnesota, 855 F2d 555, 558 (8th Cir 1988) (dismissal for alleged "misuse of the university personnel, name and resources"). Contrast with Mueller, San Filippo v Bongiovanni, 743 F Supp 327, 328 (D NJ 1990), in which the judge lamented that "[i]t is a disgrace that Rutgers, the State University of New Jersey, cannot terminate a faculty member when he or she has committed ethical violations of a high order because, for whatever reason, Rutgers has not seen fit to adopt regulations which would permit it to do so."

112. See, for example, the AAUP's case report, Academic Freedom and Tenure: Northern State College (South Dakota), 54 AAUP Bull 306 (1968), and its supplementary report on the University of Northern Colorado, University of Northern Colorado: A Supplementary Report on a Censured Administration, 71 Academe 2a (November-December 1985). 
courts of appeal to challenge their dismissals for homosexual relations with students did not think themselves guilty of grave misconduct. ${ }^{113}$ At another extreme, church-related institutions that dismiss dissidents do not believe that they are improperly limiting academic freedom (or in some cases simply do not claim to provide academic freedom). ${ }^{114}$ The third category of challenges to the system comes from troublemakers. They may be voices crying in the wilderness; they may be intolerable boors. ${ }^{115}$ Simple incapacity to perform effectively rarely surfaces.

The dedication to judgment by one's peers, that is by one's colleagues, on which the AAUP is insistent, may pose a special problem that is rather likely to crop up in the third category: that of the obnoxious colleague. A tribunal of peers might be expected to stand up against the administration; but suppose the demand for removal came from other peers? The AAUP Recommended Institutional Regulations on Academic Freedom and Tenure, first promulgated in 1957 and frequently revised, assign a primary role to a faculty hearing committee, while recognizing the ultimate authority of the governing board. The only provision they make for impaired objectivity is to prescribe that "members deeming themselves disqualified for bias or interest will remove themselves from the case, either at the request of a party or on their own initiative. Each party will have a maximum of two challenges without stated cause." 116 The Recommended Institutional Regulations do not deal with the possibility that a case may so deeply divide a faculty (especially in a small institution) that an open-minded committee cannot be found. In a few instances where such an impasse existed, assistance was solicited from colleagues in neighboring institutions. The governing board should be in a position to review a claim of pervasive bias-unless the board also is steeped in the imbroglio. 117

Tenured professors faced with dismissal generally receive due process nowadays. ${ }^{118}$ To be sure, if the system is put under severe stress by a war or a

113. See Korf $v$ Ball State University, 726 F2d 1222 (7th Cir 1984); Corstvet v Boger, 757 F2d 223 (10th Cir 1985).

114. See notes 25-26.

115. See Huang $v$ Board of Governors of the University of North Carolina, 902 F2d 1134 (4th Cir 1990) (involuntary transfer out of department, on unanimous recommendation of 23 colleagues, upheld).

116. RIR §5(c), at 26 (cited in note 102).

117. Another way out is to submit the case to arbitration, as would be commonplace under collective bargaining. There are unresolved tensions within the AAUP over the appropriate spheres of peer adjudication and outside arbitration. See 76 Academe 37 (cited in note 105).

118. One shortcoming may be in the handling of sexual harassment cases. A paper presented at the 1990 AAUP Annual Meeting, characterized as a "vulnerable" area of tenure protection,

[t]he quiet, quick way that tenured professors facing sexual harassment charges are being pressured to resign without formal review or due process. Frequently such cases are handled by the affirmative action officer and never receive formal review through faculty governance procedures. If guilty, the professor is allowed to leave without exposure, perhaps to repeat such conduct elsewhere, and without any redress to injured parties. If not guilty, the costs of fighting such charges-financially, professionally, and personally-may be too high to pay. AAUP officials report that sexual harassment is now the most frequent cause of stripping tenure. The absence of due process in these cases should alarm all faculty.

Linda Ray Pratt, Changes in the Tenure System: A Twenty Year Overview, 10 Footnotes 4 (Fall 1990). 
demagogue, fissures will develop; moreover, due process is costly for both sides. However, an administration faced with an obdurate miscreant will prevail if it will bear the costs; and the dismissal will be upheld in the courts.

Does financial exigency lead to a leak in the dike? The recognized legitimacy of letting go even tenured faculty if finances are sufficiently desperate surely impairs the security of tenure. Whether such dismissals have any adverse implications for academic freedom is a function of fairness in administering the layoffs. The AAUP's policies on financial exigency, as usual, trust in heavy faculty participation in the process.

In the decision to declare a condition of exigency and, closer to the concerns of this paper, in the identification of those who must go, the Recommended Institutional Regulations give a faculty member marked for termination "the right to a full hearing before a faculty committee."119 In that hearing, a faculty member can raise, along with other considerations, " $[w]$ hether the criteria are being properly applied in the individual case." 120 This would appear to provide an appropriate forum in which to claim that academic freedom violations lay behind that individual's release.

There have been a substantial number of financial exigency episodes in the last twenty years, and there will doubtless be more. Where controversies have gone to litigation, the predominant issue has been whether the declaration of financial exigency was, in the words of the 1940 Statement, "demonstrably bona fide." 121 The AAUP is exceedingly cautious in recognizing financial exigency; nothing less than "an imminent financial crisis which threatens the survival of the institution as a whole and which cannot be alleviated by less drastic means" 122 will justify terminations of tenured faculty, or of others during a stated term. The courts have been more indulgent in accepting institutional claims of exigency. ${ }^{123}$ Thus, defining exigency is where the action has been.

In a few cases, faculty members marked for dismissal have complained that they were selected for improper reasons. In one such case, a North Dakota jury awarded damages to a dismissed faculty member, apparently persuaded that his "squabbles with the administration" led to his nonrenewal, rather than financial exigency, which was very likely genuine. ${ }^{124}$ Other cases have made it fairly clear that a faculty member is entitled to a hearing when asserting that his or her layoff was based on improper reasons-although the

119. RIR § 4(c)(2), at 24 (cited in note 102).

120. Id.

121. 1940 Statement at 4; Appendix B at 409 (cited in note 9).

122. RIR $\S 4(\mathrm{c})(1)$, at 23 (cited in note 102).

123. See generally Robert C. Ludolph, Termination of Faculty Tenure Rights Due to Financial Exigency and Program Discontinuance, $63 \mathrm{U}$ Det L Rev 609, $610 \mathrm{nl}$ (1986), citing other extensive "recent commentary". See also Ralph S. Brown, Financial Exigency, 62 AAUP Bull 5 (Spring 1976); David Fellman, The Association's Evolving Policy on Financial Exigency, 70 Academe 14 (May-June 1984).

124. Vallejo v Jamestown College, 294 NW2d 753 (ND 1976) (separation was through nonrenewal of annual contract; nothing was said about tenure). 
hearing need not have all the refinements of a full-blown dismissal proceeding. ${ }^{125}$

Discontinuing a department or a program of instruction is another accepted ground for terminating tenured appointments-accepted by the AAUP, that is, under strict guidelines. These guidelines insist that the action be based "essentially upon educational considerations" and that "every effort" be made to relocate such displaced persons within the institution. Again, a full hearing is called for, ${ }^{126}$ one function of which must be to guard against the intrusion of improper considerations. Discontinuing an entire program would seem to appear neutral in application. But the department or program may be a small one, and all of its tenured members may be non grata. The leading case defining what a "program" is arose from the dismissal of only one tenured faculty member. ${ }^{127}$ Financial exigency had also been stipulated. Judge Skelly Wright, in an opinion that paid considerate attention to AAUP norms, recognized that "[f]inancial exigency can become too easy an excuse for dismissing a teacher who is merely unpopular or controversial or misunderstood . . . without according him his important procedural rights." 128

The most potent recent threat to the integrity of tenure arises from the prospective end of mandatory retirement for tenured professors. When retirement for age was generally abolished in $1986,{ }^{129}$ an exception was made for "any employee who has attained 70 years of age, and who is serving under a contract of unlimited tenure."130 This exception is due to expire on December 31, 1993.131 On that date, unless the exception is extended, which seems unlikely, tenured faculty will be treated like everyone else, and may not be required to retire on account of age. Of course, faculty members could still under the law be discharged or disciplined "for good cause." 132

Impending expiration of the age discrimination exception for professors led to rather hasty (and usually private) predictions by senior administrators, like one reported to this writer, that "tenure as we know it cannot survive the ending of retirement for age." Why should this be so? Because, it was believed, faculty members would linger on until death or physical disability

125. RIR $\S 4(\mathrm{c})(2)$, at 24 (cited in note 102). The cases include Mabey $v$ Reagan, 537 F2d 1036 (9th Cir 1976); Bignall v North Idaho College, 538 F2d 243 (9th Cir 1976); see Ludolph, 63 U Det L Rev at 620-26 (cited in note 123).

A significant recent case is Johnston-Taylor $v$ Gannon, 907 F2d 1577 (6th Cir 1990). Two professors selected for dismissal in an alleged financial exigency complained that the procedures of a collective bargaining agreement were inadequate. One had tenure; one was on a "continuing appointment," which the court treated as equivalent to tenure, so that both could invoke constitutional due process under Perry, 408 US 593, and were entitled to a proper hearing.

126. RIR $\S 4(d)$, at $24-25$ (cited in note 102).

127. Browzin v Catholic University of America, 527 F2d 843 (DC Cir 1975).

128. Id at 847 .

129. Age Discrimination in Employment Act Amendments of 1986, Pub L No 99-592, 100 Stat 3342; 29 USC $\S 621$ (1988).

130. 29 USC $\S 631$ (d) (from 1989 amendment) (1988, Supp 1990).

131. Pub L No 99-592 §§ 2(c), 6(b).

132. 29 USC $\S 623(f)(3)$. 
forced them out, thus lowering the quality of teaching and frustrating the prospects of recruitment and promotion for younger scholars. ${ }^{133}$

Such concerns were given temperate consideration by Oscar Ruebhausen, the distinguished lawyer who chaired the Commission on College Retirement that produced a very useful report in $1986 . .^{134}$ Ruebhausen (independently of the commission) pointed out correctly that retirement upon reaching a certain age had long been the expectation-rarely challenged-in higher education. Believing that universities should have some flexibility in dealing with aged faculty, he proposed that professors, on accepting tenure, should also accept a long-term contract, possibly lasting thirty-five years. On its expiration, tenure would end, and any longer retention would be the subject of new contracts. ${ }^{185}$ The feasibility and legality of Ruebausen's proposals were rebutted by Professor Finkin. ${ }^{136}$ We are not aware of any initiative to implement them. We have outlined them as an example of a cautious reaction to sometimes incautious alarms.

No one will be able to assert with assurance, until some time after 1993, whether the alarms have been well founded. Two substantial studies attempt to explore the future. One, mandated by Congress, ${ }^{137}$ is being carried out by the National Academy of Sciences, and is still in process. The other, financed by foundations, was performed at Princeton University under the direction of Professor Albert Rees. It is awaiting publication. ${ }^{138}$

Rees' study, which focused on the arts and sciences faculties of doctoral degree-granting institutions and selective liberal arts colleges, states as its principal conclusion that "statements of alarm and concern have surprisingly little basis in fact, and are considerably overblown." 139 The project did not have to rely on predictions. In several states, mandatory retirement, especially in public institutions, has been "uncapped" for several years. The Project found "no significant differences in mean retirement age between capped and uncapped public universities or capped and uncapped liberal arts colleges." 140 We do not think it appropriate to divulge more fully the findings of a study that, as we write, is still unpublished. But we think that it will dispel

133. See generally Martin L. Levine, Age Discrimination and the Mandatory Retirement Controversy (Johns Hopkins Univ Press, 1988); Karen Holden \& W. Lee Hansen, eds, The End of Mandatory Retirement: Effects on Higher Education (Jossey-Bass, 1989); Report, Ending Mandatory Retirement in Higher Education, 76 Academe 52 (January-February 1990).

134. Commission on College Retirement, A Pension Program for College and University Personnel, in Oscar M. Ruebhausen, ed, Pension and Retirement Policies in Colleges and Universities; An Analysis and Recommendations (Jossey-Bass, 1990).

135. Oscar M. Ruebhausen, The Age Discrimination in Employment Act Amendments of 1986 : Implications for Tenure and Retirement, $14 \mathrm{~J}$ Col \& Univ L 561 (1988).

136. Matthew W. Finkin, Tenure After an Uncapped ADEA: A Different View, $15 \mathrm{~J}$ Col \& Univ L 43 (1988).

137. 29 USC $\S 622(a)$.

138. Albert Rees \& Sharon P. Smith, Faculty Retirement in the Arts and Sciences (Princeton Univ Press, forthcoming 1991).

139. Id at ch 6 (conclusions).

140. Id. 
any notion that the end of mandatory retirement will place tenure under substantial stress.

In sum, there are no major leaks in the dike. Tenure, always under attack, seems to be generally secure.

\section{VII}

\section{Academic Freedom for Academics Who Do Not Have Tenure}

If, as this article has reaffirmed, academic tenure serves substantially to protect academic freedom, we still must consider, albeit briefly, what protects the academic freedom of the significant minority of teachers and researchers who have not yet attained tenure or who have been kept outside the tenure system.

The 1940 Statement asserts that "during the probationary period a teacher should have the academic freedom that all other members of the faculty have,"141 and the AAUP asserts in its Recommended Institutional Regulations that "[a]ll members of the faculty, whether tenured or not, are entitled to academic freedom."'142 Merely setting forth these assertions does not, however, ensure academic freedom for faculty members who are subject to nonreappointment at an administration's pleasure, and one can fairly wonder whether, if tenure is vital for academic freedom, it is only the tenured whose academic freedom is truly protected. ${ }^{143}$

Our experience shows that there is some truth, as well as considerable paternalism, in the statement that the best protection for the academic freedom of the nontenured is a strong tenured faculty. Administrators with a strong devotion to academic freedom have on occasion provided this protection too-sometimes, as AAUP's Alexander Meiklejohn Awards have testified, with commendable courage. ${ }^{144}$ The hope of protection from above, however, is no substitute for specific procedural safeguards. The need for the latter became manifest during the McCarthy era, when the number of tenured professors dismissed in disregard of principles of academic freedom was relatively small compared with the hundreds of politically suspect faculty members serving on term appointments that were not renewed. These faculty members were afforded no opportunity to contest the action. ${ }^{145}$ The AAUP responded to this situation in its 1956 report on Academic Freedom and Tenure in the Quest for National Security, calling for a faculty review procedure in a case of nonreappointment on grounds that allegedly violate academic freedom, with a full adjudicative hearing to occur upon

141. 1940 Statement at 4, Appendix B at 408 (cited in note 9).

142. RIR $\S 9(\mathrm{a})$, at 28 (cited in note 102 ).

143. See Van Alstyne, 57 AAUP Bull at $331-33$ (cited in note 2).

144. The Alexander Meiklejohn Award is presented to an American college or university administrator or trustee in recognition of an outstanding contribution to academic freedom. See, for example, The Seventeenth Alexander Meiklejohn Award, 74 Academe 42 (September-October 1988).

145. Lionel S. Lewis, Cold War on Campus: A Study of the Politics of Organizational Control 29-47 (Transaction Books, 1988). 
establishment of a prima facie case. ${ }^{146}$ This recommended procedural safeguard for nontenured faculty was adopted by a wide segment of the academic community within a few years. So, in the next decade, was the AAUP's 1964 Standards for Notice of Nonreappointment, calling for notice by March 1 in the first year of appointment, by December 15 in the second year, and twelve months in advance thereafter. The deadlines for notice provided affected faculty members with time to relocate, or to seek reconsideration of a negative decision before their existing appointments expired; along with other procedural developments discussed in Parts VII A$\mathrm{C}$, they also contributed to a more orderly and equitable system of evaluation.

A. Obtaining Reasons for a Nonreappointment Decision and Opportunity for Review of the Decision

The probationary faculty member who refused to testify before a congressional committee about his political associations, and who the next day was notified by his dean that he was not being reappointed, had a pretty good idea of the reason for the decision. More often than not, however, notice of nonreappointment unaccompanied by any explanation left the faculty member unclear why the notice was issued. A person in this plight was ill informed to determine whether and on what grounds to seek review of the decision. A quarter of a century ago, relatively few institutions, and very few prestigious universities and liberal arts colleges, had policies calling for the issuance of reasons for nonreappointment. In 1964 the AAUP itself published an advisory letter from its staff that cautioned against providing reasons. The letter offered arguments that in retrospect seem embarrassingly overprotective of those who make the decision (because they need "the utmost latitude in determining who will be retained") and embarrassingly paternalistic toward the junior faculty member who is left in the dark (in order to spare upsetting the poor candidate by revealing reasons "that are either very difficult to discuss frankly or which the faculty member cannot appreciate"). 147

Increasing demand for openness in the decision-making process, and for grievance procedures that would afford opportunity for review of allegedly arbitrary and unfair decisions, led AAUP's Committee A into a two-year examination that resulted in the Association's 1971 Statement on Procedural Standards in the Renewal or Nonrenewal of Faculty Appointments. ${ }^{148}$ The new procedural standards, after explaining the arguments for and against providing reasons for nonreappointment, came down clearly in favor of providing reasons when the faculty member so requests. Upon such request, the standards called for an oral explanation of the decision against reappointment and then, upon further request, for a written statement of the reasons. The standard extended the right of review to an allegation of

146. Academic Freedom and Tenure in the Quest for National Security, 42 AAUP Bull 61 (1956).

147. Letter Number Thirteen, 50 AAUP Bull 85 (1964).

148. 1990 AAUP Red Book at 15 (cited in note 11). 
inadequate consideration in the decision-making process, rather than limiting appeals to decisions allegedly based on impermissible factors, and thus violative of academic freedom. The procedures thereby afforded access to a faculty grievance committee which, if it found merit in the allegation, could remand the matter to the decision-making body for its further consideration.

The 1971 procedural standards had just been published when the case of Board of Regents of State Colleges $v$. Roth came before the Supreme Court. 149 The AAUP, in a brief amicus curiae, supported the contention of Professor Roth, a nontenured faculty member in the Wisconsin State University system who was challenging nonreappointment, that he was entitled under the fourteenth amendment to due process. The AAUP's brief, citing the procedural standards extensively, argued for "minimal due process, as exemplified by a statement of reasons and a limited hearing." 150 As we have observed earlier, ${ }^{151}$ the Court, holding that Roth had not been deprived of liberty or property, rejected his constitutional claim. It noted, however, that its analysis of Roth's rights under the Constitution did not speak to whether it is "appropriate or wise in public colleges and universities" to afford "opportunity for a hearing or a statement of reasons for nonretention," citing AAUP's procedural standards to illustrate what might be afforded. 152

Even though, after Roth, reasons and opportunity for review are not constitutionally required, and though many university attorneys argue that it is safer to give no reasons than to give and then have to defend them, policies calling for reasons and review have become quite common. What was the exception twenty-five years ago now seems to be pretty much the rule. ${ }^{153}$

\section{B. Access to Faculty Personnel Records in Contesting Nonreappointment}

Access to personnel records is an important remaining issue, and not only in the sense that is has not yet been discussed in this paper. Key elements of this issue that bear on procedural safeguards for nontenured faculty members remain to be resolved in the academic community. Colleges and universities traditionally have been left largely to themselves, with practices varying widely, in determining which records are closed and which are open, both to the subject faculty member and to others. The issue became one of sharp concern over the past decade, in the context of judicially compelled disclosure

149. 408 US 564 (1972).

150. AAUP's Brief as Amicus Curiae, Board of Regents of State Colleges v Roth 10-14 (No 71-162) (January 1972).

151. See notes $90-93$ and accompanying text.

152. 408 US at 578-79. See also William W. Van Alstyne, The Supreme Court Speaks to the Untenured, 58 AAUP Bull 267-70 (1972).

153. An additional salutary development in procedures for review available to nontenured faculty members involves protections against improper discrimination. AAUP's Recommended Institutional Regulations and its procedural standards as now revised, have come to specify a complaint of discrimination in nonreapointment, as well as a complaint of violation of academic freedom, as potentially involving impermissible actions that warrant adjudication through a full hearing of record if a prima facie case is established. Moreover, statistical evidence of improper discrimination can be used in establishing the case. RIR at 28 (cited in note 102). 
in the processing of discrimination complaints. ${ }^{154}$ Markedly different conclusions of law from different federal appellate courts were resolved earlier in 1990 when the Supreme Court handed down its decision in University of Pennsylvania v. EEOC, unequivocally rejecting any claim of privilege from disclosure. ${ }^{155}$ Henceforth, we can presume, a faculty plaintiff who is litigating under federal antidiscrimination law will have access to all documentation in her or his files, and in others' files as well, that arguably relates to the plaintiff's complaint.

Thus, the law is clear regarding judicial or administrative proceedings pursuant to discrimination complaints; but what of internal appeals of decisions to deny reappointment? An AAUP subcommittee has concluded, with respect to complaints involving a claim of violation of academic freedom or of antidiscrimination policy, that the faculty review committee should be granted access to relevant documentation in the files of the complainant and of others, and should have the discretion to share it with the complainant under certain circumstances. Whether and how these circumstances should be specified is still being discussed, as is whether committees should have access to relevant documentation in all cases in which a nonreappointment decision is alleged to be unfair or irregular, or only those in which the faculty member alleges violation of academic freedom or discrimination. Beyond access to documentation, there is the question whether the faculty complainant, at least when discrimination is alleged, should have the same right of access (without depending on the faculty committee's discretion) that a plaintiff now has in a judicial proceeding. This issue sharply divided the AAUP's subcommittee in its initial report. These are but some of the questions relating to access to personnel records that await resolution.

\section{Delaying the Granting of Tenure by Lengthening the Probationary Period}

As emphasized earlier, the seven-year maximum set by the 1940 Statement allows a probationary period that is quite long when measured against apprenticeship periods common in other skilled professions and occupations. Pressures to allow an even longer probation abound, however. These pressures come from both faculty and administration (albeit usually for different reasons) in the form of proposed changes in general policy and proposed exceptions in individual cases. They come in a fairly steady stream to the AAUP, especially when it is seen that AAUP-recommended standards do not permit a particular lengthening that is sought. The AAUP's blessing on a breach of its rules is solicited; the AAUP is then often cast as the villain for not endorsing an arrangement the parties immediately involved consider the best way to solve a problem.

154. For AAUP's position when the issue initially surfaced, see A Preliminary Statement on Judicially Compelled Disclosure in the Nonrenewal of Faculty Appointments, 67 AAUP Bull 27, 28 (1981).

155. 110 S Ct 577 (1990). 
One device for lengthening the probationary period is to decline to grant credit toward tenure for previous service at another institution; despite the 1940 Statement's requirement that at least three years of such service should be credited. From the outset, some major universities, otherwise models in terms of their general adherence to the 1940 Statement and its derivative principles and standards, have simply declined to give probationary credit for previous service elsewhere. As pressures to extend probationary time grew, with numerous additional colleges and universities either refusing to continue crediting previous service or calling upon the AAUP to reconsider the requirement, the AAUP in 1978 adopted an interpretive statement. ${ }^{156}$ This statement acknowledges that it may be in the best interests of all parties to determine at the time of initial appointment whether credit for prior service can be waived, requiring a full seven-year probationary period at the current institution. If certain conditions (including faculty approval of the policy) prevail, the statement declares, the AAUP will not consider an agreement to waive credit to be "a violation of principles of academic freedom and tenure warranting an expression of Association concern."157

A second device for allowing more probationary time has been to place new faculty members who have not completed the terminal degree in a kind of preprobationary status, with the probationary years commencing only after the degree is obtained. This practice is also unacceptable under the 1940 Statement, which applies the probationary period to all full-time faculty members regardless of academic rank and credentials. Some institutions place a cap (usually two years) on the amount of full-time pre-Ph.D. service that will be permitted, but others permit such service to go on and on; the AAUP has reported on cases in which probationary time began to be counted only after the faculty member's years of service had already exceeded the seven years of probation that the 1940 Statement permits. ${ }^{158}$ Interest in allowing an extension of the probationary period for parents of young children has gathered momentum in recent years and has been the subject of considerable debate. Some major research universities have adopted policies to that effect; others have rejected them. Most such policies that have been considered would permit only one or two one-year extensions.

Pleas for extensions of probation to meet special needs in particular academic fields have been too numerous and diverse to be listed here. One prominent example is the person recruited to a medical school faculty to perform simultaneously as researcher, teacher, and clinician. Meeting the requirements for tenure within seven years in any one of these capacities is difficult enough, so the persuasive argument for more probationary time goes, but meeting them in all three capacities is well nigh impossible.

156. AAUP, On Crediting Prior Service Elsewhere as Part of the Probationary Period, in 1990 AAUP Red Book at 69 (cited in note 11 ).

157. Id at 70 .

158. See Pennsylvania State University: A Report on Two Cases of Excessive Probation, 72 Academe 15a19a (May-June 1986). 
If a university yields to the urging of its medical school and grants an extension, it is likely to confront similar demands from, for example, its business school, its school of social work, and its computer science department. If extensions are granted to persons rearing children, it becomes more difficult to refuse them to those who need to complete their doctoral degrees or who are saddled with prior service elsewhere. The increase in what one needs to do to prove oneself has indeed been explosive in some academic fields, for there is always more to learn and to do. Extensions of the stated maximum probationary period, if permitted for less than highly extraordinary reasons, will tend to be granted with increasing frequency and casualness. The resulting general erosion of the fixed probationary period would undermine the system of academic tenure and weaken the safeguards it provides for academic freedom.

\section{Avoiding the Granting of Tenure by Keeping Faculty Members Out of the Tenure System}

The procedural safeguards developed and broadly accepted by the academic community over the past fifty years, recounted in Parts VII A-C, have done a good deal to buttress the 1940 Statement's assertion that probationary faculty should have the same academic freedom as their tenured colleagues. Most regrettably, however, increasing numbers of faculty members are being excluded from the system of tenure and probation. Neither tenured nor probationary, they serve with scant protection for their academic freedom.

Under the AAUP's recommended standards, all full-time faculty appointments are either probationary or with continuous tenure; exceptions are limited to "special appointments clearly limited to a brief association with the institution, and reappointments of retired faculty members on special conditions." 159 Many colleges and universities have treated teachers in clinical programs or of elementary or remedial courses as holders of "special appointments" outside the system of probation and tenure, even though the courses may carry academic credit. The teacher's association with the institution may be of brief duration, but it may just as likely continue indefinitely through successive one-year (or even one-semester) appointments renewable at the administration's pleasure. Often these appointments are designated "temporary," although a faculty member may have served under them for ten or twenty or more years. "Temporary" in such cases does not mean what it is supposed to mean in the English language; it is twisted to mean that the regular rules (such as standards for notice, obtaining reasons for nonretention, and access to grievance procedures) do not apply. ${ }^{160}$

159. RIR § 1 (b) at 21 (cited in note 102).

160. Equally offensive to the English language and to concepts of fairness is the placement of a faculty member on an appointment designated as "part-time," and paying dismally low per-course wages, with teaching assignments that meet or even exceed what for more fortunate colleagues is a full-time load. On the use and abuse of part-time appointments, see The Status of Part-Time Faculty, in 1990 AAUP Red Book at 52 (cited in note 11). 
Placing faculty members in this kind of inferior status because their responsibilities are deemed insufficiently lofty to let them into the tenure system is bad enough. Worse, as an abuse of principles of academic freedom and tenure, is the placement on these nontenure-track appointments of faculty members whose academic responsibilities are indistinguishable from those of their probationary and tenured colleagues. Managerial concerns for flexibility and economy lie behind these abuses but do not justify them. The devices are academically unsound and plainly unfair. ${ }^{161}$ Until the managers of higher education bring into the tenure system the large numbers of our colleagues who are being improperly kept out of it, academic freedom for them will be poorly protected and for all will be less than secure.

\section{VIII}

\section{ConcLusion}

Tenure, like any other large, occasionally inefficient system, will probably remain under attack for years to come. Anecdotal evidence of inferior scholars and teachers shielded by tenure makes a powerful hostile argument, though not a valid one. The economic and social costs of the tenure system are, we believe, outweighed by the fact that tenure is vital to academic freedom. No other proposed alternative (such as legal defenses, internal safeguards, less-than-career tenure, or tenure review) can provide adequate protection to the academic community. A greater danger to the tenure system than outright abrogation is continued circumvention. Deficiencies in the due process accorded fired professors, dubious financial exigency claims by colleges and universities, the discontinuation of entire programs, and, especially, runaway expansion of nontenure-track positions threaten not to tear down the tenure system, but to weaken it severely.

161. For a report on the range of problems arising from these practices (and their prevalence), see On Full-Time Non Tenure-Track Appointments, in 1990 AAUP Red Book at 40 (cited in note 11). 
